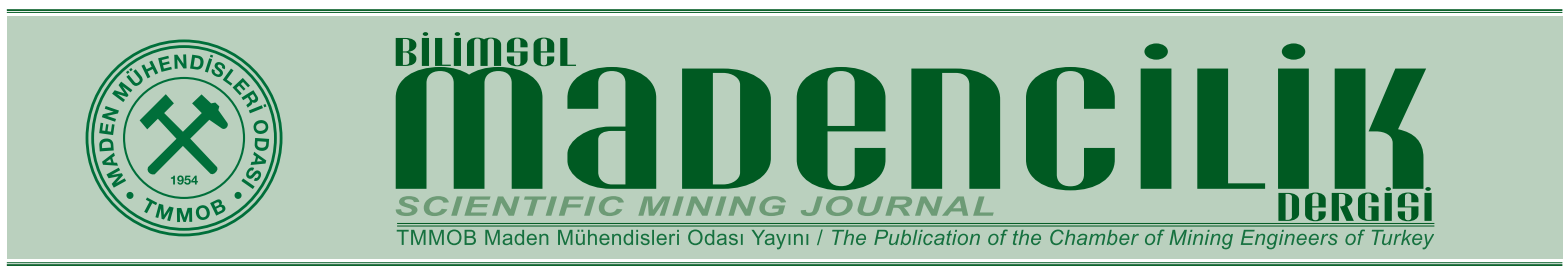

Orijinal Araştırma / Original Research

\title{
INVESTIGATION OF THE AMENABILITY OF A COPPER-RICH REFRACTORY GOLD ORE TO CYANIDE LEACHING
}

\author{
BAKIR IÇERIĞi YÜKSEK REFRAKTER BIR ALTIN CEVHERININ SIYANÜR LIÇINE \\ UYGUNLUĞUNUN ARAŞTIRILMASI
}

\author{
Deus Albert Msumange ${ }^{\mathrm{a},{ }^{*}}$, Ersin Yener Yazıcl ${ }^{\mathrm{a},{ }^{, * *}}$, Oktay Celep ${ }^{\mathrm{a},{ }^{, * *}}$, Hacı Deveci ${ }^{\mathrm{a}, * * * *}$ \\ ${ }^{a}$ Hydromet B\&PM Research Group, Division of Mineral\&Coal Processing, Department of Mining Engineering, Karadeniz Technical University (KTU), 61080, Trabzon, \\ TURKEY.
}

$\begin{array}{ll}\text { Geliş Tarihi / Received } & : 15 \text { Mayıs / May } 2020 \\ \text { Kabul Tarihi / Accepted } & : 15 \text { Ağustos / August } 2020\end{array}$

Keywords:

Gold,

Copper-gold ores,

Cyanide leaching,

Acid pretreatment,

Ultra-fine grinding,

Refractory gold ore.

\section{ABSTRACT}

The production of gold from refractory gold ores has been increasing due to the exhaustion of free milling gold ores. The presence of cyanicides (e.g., copper minerals) and encapsulation of gold in minerals such as pyrite and arsenopyrite are common reasons for refractoriness of gold ores. In this study, the amenability of a copper-rich gold ore (108 $\mathrm{g} / \mathrm{t} \mathrm{Au}, 1.60 \% \mathrm{Cu}$ ) to cyanide leaching was investigated. Direct cyanide leaching of the ore showed that the gold extraction was very low by $18.4 \%$ over $24 \mathrm{~h}$., indicating that the ore is highly refractory. Sulphuric acid pretreatment for the removal of acid-soluble copper was found to be not effective to achieve high gold extractions at the subsequent cyanide leaching. Leaching at high $\mathrm{NaCN}$ concentrations (1-8 g/L) yielded limited Au extractions of $\leq 47.2 \%$. Ultra-fine grinding (UFG) $\left(\mathrm{d}_{80}: 8-73 \mu \mathrm{m}\right)$ as a pretreatment route followed by cyanide leaching also could provide Au recoveries of just below $54.1 \%$. The findings showed that the ore is double-refractory and needs the employment of more effective pretreatment process(es) to achieve acceptable gold extractions (>90\%) in subsequent cyanidation stage.

\section{öz}

Anahtar Sözcükler: Altın,

Bakırlı altın cevherleri, Siyanür liçi,

Asit ön işlemi,

Çok ince öğütme,

Refrakter altın cevheri.
Serbest altın içeren cevherlerin giderek tükenmesi nedeniyle refrakter altın cevherlerinden altın üretimi artmaktadır. Siyanür tüketen minerallerin (bakır mineralleri gibi) varlığı ve altının pirit ve arsenopirit gibi mineraller içerisinde kapanım halinde bulunması altın cevherlerindeki refrakterliğin yaygın nedenleri arasında yer almaktadır. Bu çalışmada, bakırca zengin bir altın cevherinin (108 g/t Au, \%1,60 Cu) siyanür liçine uygunluğu araştırılmıştır. Siyanür liçinde elde edilen düşük $(\% 18,4)$ altın kazanımı, cevherin yüksek derecede refrakter bir cevher olduğunu göstermektedir. Sülfürik asit ön işlemi ile asitte çözünen bakııın uzaklaştırılması, takip eden siyanür liçinde yüksek altın kazanımlarına ulaşılmasında etkili olmamıştır. Yüksek NaCN konsantrasyonlarında (1-8 g/L) yapılan testlerde, sınırlı altın kazanımları $(\leq \% 47,2)$ elde edilmiştir. Siyanür liçinden önce ön işlem olarak uygulanan çok ince öğütme $\left(d_{80}: 8-73 \mu \mathrm{m}\right)$ sonrası altın kazanımları \%54,1'in altında kalmıştır. Elde edilen sonuçlar cevherin çift yönlü refrakter bir cevher olduğunu ve siyanür liçi aşamasında kabul edilebilir (>\%90) altın kazanımlarına ulaşmak için daha etkili ön işlem(ler)in uygulanmasının gerekli olduğunu göstermiştir.

\footnotetext{
* Sorumlu yazar / Corresponding author: msudeak8@gmail.com•https://orcid.org/0000-0002-0809-7228

** eyazici@ktu.edu.tr•https://orcid.org/0000-0002-8711-0784

*** ocelep@ktu.edu.tr•https://orcid.org/0000-0001-9024-4196

**** hdeveci@ktu.edu.tr•https://orcid.org/0000-0003-4105-0912
} 


\section{INTRODUCTION}

Following the rapid diminution of free milling gold ores, the production of gold from refractory ores has been receiving more attention across the globe. Ores are described as refractory when they are not essentially amenable to direct cyanidation i.e., low gold recoveries $(<80 \%)$ under typical cyanide leaching conditions (Celep, 2015; Marsden and House, 2006). Several factors have been discussed broadly as the cause of refractoriness. Carbonaceous matter (i.e. inorganic and/or organic carbon) present in the ore is one of a common cause of low gold recovery because it easily adsorbs gold in solution and leads to "preg-robbing" phenomenon. Encapsulation of gold in sulphide (commonly pyrite and arsenopyrite) and/or nonsulphide gangue minerals appears to be the most prevalent factor of refractoriness (Habashi, 1999; Marsden and House, 2006). The existence of excessive cyanide- and oxygen-consuming phases (e.g., reactive copper minerals, pyrrhotite) may also severely interfere with the cyanide leaching of gold. Moreover, gold ores in which gold occur as alloys electrum, $\mathrm{AuTe}_{2}$, $\mathrm{AuSb}_{2}$ etc. can exhibit refractory behaviour due to the remarkably slow (or even no) dissolution of such gold alloys in cyanide solutions (Celep, 2015; Chryssoulis and McMullen, 2016).

In recent years, copper-rich gold ores have attracted particular interest and hence the production of gold from copper-rich gold ores has been increasing (Sceresini and Breuer, 2016). As of 2009 , above $20 \%$ of the total world's Au production was from $\mathrm{Cu}-\mathrm{Au}$ ores (Fleming et al., 2011). Porphyry copper deposits are essentially one of the basic types of the mineral body containing gold. The typical gold and copper grades in these deposits are 0.2-2 g/t and 0.2$1 \%$, respectively (Kesler et al., 2002; Sinclair, 2007). Turkey is also one of the countries having both free milling and refractory gold/silver ores including those ores with high copper content. Table 1 summarizes some important gold/silver ore deposits with their metal $(\mathrm{Au}, \mathrm{Ag}, \mathrm{Cu})$ grades and employed processing routes in Turkey.

Gold recovery from gold-copper ores presents various technical drawbacks ascribed to the

Table 1. Some gold/silver ore deposits with metal grades and applied processing routes in Turkey

\begin{tabular}{|c|c|c|c|c|c|}
\hline Location & $\begin{array}{l}\text { Au grade } \\
(\mathrm{g} / \mathrm{t})\end{array}$ & $\begin{array}{l}\text { Ag grade } \\
(\mathrm{g} / \mathrm{t})\end{array}$ & Cu Content & $\begin{array}{l}\text { Processing } \\
\text { Method }\end{array}$ & $\begin{array}{l}\text { Ore } \\
\text { Type }\end{array}$ \\
\hline Bergama/Ovacık(İzmir) & $9^{\text {a }}$ & $11^{a}$ & - & ATL & FM \\
\hline Küçükdere (Balıkesir) & $5^{a}$ & $11.8^{a}$ & - & ATL & FM \\
\hline Kaymaz (Eskişehir) & $7.9^{\mathrm{a}}$ & $6.4^{\mathrm{a}}$ & - & ATL & FM \\
\hline Kışladağ (Uşak) & $1.2^{\mathrm{a}}$ & $0.9^{a}$ & - & $\mathrm{HL}$ & FM \\
\hline Mastra (Gümüşhane) & $12.13^{b, c}$ & $5.5^{b, c}$ & $<1.1 \%^{\mathrm{b}}$ & ATL & $F M \& R$ \\
\hline $\begin{array}{l}\text { Çöpler (Erzincan) } \\
\text { (Oxide ore) }\end{array}$ & $1.4^{d}$ & - & $\begin{array}{c}0.03 \%(\text { Some } \\
\text { zones } \leq 3.9 \%)^{d}\end{array}$ & $\mathrm{HL}$ & FM \\
\hline $\begin{array}{l}\text { Çöpler (Erzincan) } \\
\text { (Sulphide ore) }\end{array}$ & $2.60^{\mathrm{e}}$ & $6.70^{e}$ & - & POX & $\mathrm{R}$ \\
\hline Efemçukuru (İzmir) & $13.3^{f} 62^{g}$ & $110^{f}$ & $0.35 \% \mathrm{Cu}^{\mathrm{g}}$ & $\mathrm{F}+\mathrm{HL}$ & $\mathrm{R}$ \\
\hline Gümüşhane village (Artvin) & $0.3^{\mathrm{f}, \mathrm{h}}$ & - & $0.3 \%$ f,h & Under development & R \\
\hline Cerattepe (Artvin) & $4.2^{f}$ & $151^{f}$ & $5.2 \%^{f}$ & - & R \\
\hline Hot Maden (Artvin) & $10^{i}$ & - & $2.2 \%^{i}$ & - & $\mathrm{R}$ \\
\hline Gümüşköy (Kütahya) & - & $127^{a}$ & - & ATL & $R$ \\
\hline
\end{tabular}

ATL: Agitation tank leaching; HL: Heap leaching; F: Flotation; POX: Pressure oxidation; FM: Free milling; R: Refractory

a Celep (2011); b Bas et al., (2012); c URL-1 (2013); d Bascombe et al., (2013); e URL-2 (2020); ${ }^{\text {Y }}$ igit (2006); Ahlatcı et al., (2016); h Akçay and Gündüz (2004); ' URL-3 (2016) 
ready dissolution of most minerals of copper in cyanide solutions (Table 2) leading to high cyanide consumption and exorbitant reagent costs. When subjected to cyanide-deficient solutions, certain copper minerals (e.g., chalcopyrite) can also exhibit preg-borrowing peculiarities, which are reversible (Marsden and House, 2006). High cyanide consumption through the formation of stable copper cyanide complexes (Equations 1-5) may even render the process uneconomic.

$$
\begin{aligned}
& \mathrm{Cu}^{2+}+2 \mathrm{CN}^{-} \rightarrow \mathrm{Cu}(\mathrm{CN})_{2} \\
& \mathrm{Cu}_{2} \mathrm{O}+6 \mathrm{CN}-\mathrm{H}_{2} \mathrm{O} \rightarrow 2 \mathrm{Cu}(\mathrm{CN})_{3}{ }^{2-}+2 \mathrm{OH}^{-} \\
& \mathrm{Cu}_{2} \mathrm{~S}+7 \mathrm{CN}^{-}+1 / 2 \mathrm{O}_{2}+\mathrm{H}_{2} \mathrm{O} \rightarrow 2 \mathrm{Cu}(\mathrm{CN})_{3}{ }^{2-}+2 \mathrm{OH}^{-} \\
& + \text {CNS } \\
& 2 \mathrm{CuO}+7 \mathrm{CN}^{-}+\mathrm{H}_{2} \mathrm{O} \rightarrow 2 \mathrm{Cu}(\mathrm{CN})_{3}{ }^{2-}+2 \mathrm{OH}+\mathrm{CNO} \\
& 2 \mathrm{CuS}+8 \mathrm{CN}^{-}+1 / 2 \mathrm{O}_{2}+\mathrm{H}_{2} \mathrm{O} \rightarrow 2 \mathrm{Cu}(\mathrm{CN})_{3}{ }^{2-}+2 \mathrm{OH}^{-} \\
& +2 \mathrm{CNS}
\end{aligned}
$$

Table 2. The solubility of copper minerals in $0.1 \% \mathrm{NaCN}$ solutions (Marsden and House, 2006; Hedley and Tabachnick,1958)

\begin{tabular}{lccc}
\hline Mineral & Formula & \%Cu dissolved $\left(23^{\circ} \mathrm{C}\right)$ & \%Cu dissolved $\left(45^{\circ} \mathrm{C}\right)$ \\
\hline Azurite & $\mathrm{Cu}_{3}\left(\mathrm{CO}_{3}\right)_{2}(\mathrm{OH})_{2}$ & 94.5 & 100.0 \\
Malachite & $\mathrm{Cu}_{2} \mathrm{CO}_{3}(\mathrm{OH})_{2}$ & 90.2 & 100.0 \\
Chalcocite & $\mathrm{Cu}_{2} \mathrm{~S}$ & 90.2 & 100.0 \\
Covellite & $\mathrm{CuS}$ & - & - \\
Native Copper & $\mathrm{Cu}$ & 90 & 100.0 \\
Cuprite & $\mathrm{Cu}_{2} \mathrm{O}$ & 85.5 & 100.0 \\
Bornite & $\mathrm{Cu}_{5} \mathrm{FeS}_{4}$ & 70 & 100.0 \\
Chalcopyrite & $\mathrm{CuFeS}_{2}$ & 5.6 & 8.2 \\
Tetrahedrite & $\left(\mathrm{Cu}, \mathrm{Fe}_{2}, \mathrm{Ag}_{2}, \mathrm{Zn}\right)_{12} \mathrm{Sb}_{4} \mathrm{~S}_{13}$ & 21.9 & 43.7 \\
\hline
\end{tabular}

In cyanide leaching of free-milling gold ores, typical cyanide consumption is $0.25-2 \mathrm{~kg} / \mathrm{t} \mathrm{NaCN}$ (Marsden and House, 2006). However, gold ores containing $>0.5 \%$ Cu cannot be processed in an economic way on the grounds that every $1 \%$ reactive copper consumes $30 \mathrm{~kg} / \mathrm{t} \mathrm{NaCN}$ (Muir, 2011). If the ore contains copper sulphides, cyanide consumption could further increase up to $51.5 \mathrm{~kg} / \mathrm{t}$ for each per cent of reactive copper (Sceresini and Breuer, 2016). Intensive cyanide leaching by maintaining a $\mathrm{CN}$ : $\mathrm{Cu}$ ratio of $>4$ can be used to achieve acceptable gold extractions (Fleming, 2011; Bas et al., 2015; Deveci et al., 2018). Pretreatment and/or alternative methods are indispensable before leaching by cyanidation of refractory gold ores to enhance gold recoveries. Potential options for the treatment of copper-rich gold ores, in particular, include the removal of copper sulphides by flotation followed by cyanide leaching, the elimination of copper in acid/alkaline solutions prior to cyanide leaching, the use of alternative lixiviant systems (e.g., thiosulphate leaching, ammoniacal cyanide leaching) (Ahlatcı et al., 2018; Bas et al., 2015; Yazici et al., 2015) and intensive cyanide leaching (i.e., leaching at high cyanide concentrations) followed by cyanide recovery (e.g, SART process) (Yilmaz et al., 2019; Sceresini and Breuer, 2016). Depending on the cause(s) of the refractoriness, other pretreatment options such as ultrafine grinding, pressure oxidation, roasting and biooxidation can be used prior to cyanide leaching (Celep, 2015).

In this study, the amenability of a copper-rich refractory gold ore to cyanide leaching was investigated. The effect of $\mathrm{H}_{2} \mathrm{SO}_{4}$ pretreatment for reactive copper removal on the gold extraction in the subsequent cyanide leaching was examined. Effect of cyanide concentration in the range of 1-8 $\mathrm{g} / \mathrm{L} \mathrm{NaCN}$ was also tested on the cyanide leaching of gold. Ultra-fine grinding (UFG) as a pretreatment method prior to cyanidation of the ore was also investigated. 


\section{EXPERIMENTAL}

\subsection{Ore Sample}

The ore sample utilised in this work was from copper-rich zones of Mastra-Gümüşhane deposit. The crushed ore $(-4 \mathrm{~mm})$ was ground to $73 \mu \mathrm{m}$ $\left(d_{80}\right)$ by using a laboratory rod mill over $30 \mathrm{~min}$. The ground ore was riffled and then divided by rotary cone sample divider (Fritsch Laborette 27) to obtain representative sub-samples for characterization and leaching tests. Table 3 shows the chemical analysis of the ore sample. XRF and ICP-MS were used for the analysis of whole-rock and trace elements, respectively, in an accredited analytical laboratory (Argetest, Turkey). An atomic absorption spectrometer (AAS; Perkin Elmer AAnalyst 400) was also used for the analysis of $\mathrm{Au}, \mathrm{Ag}$, and $\mathrm{Cu}$ from leach solutions or aliquots obtained from hot digestion of the ore sample or leaching residue within aqua regia. The analytical results have shown that the sample is rich in gold and copper, containing $108 \mathrm{~g} / \mathrm{t}$ and $1.6 \%$, respectively. According to the data collected from XRD and ICP-MS, the main phases of the ore were identified to be quartz $\left(67.3 \% \mathrm{SiO}_{2}\right)$ and pyrite $\left(\mathrm{FeS}_{2}\right)$ (Figure 1). Bas et al. (2012) reported that samples from a different zone in the same field contained chalcopyrite $\left(\mathrm{CuFeS}_{2}\right)$, covellite (CuS) chalcocite $\left(\mathrm{Cu}_{2} \mathrm{~S}\right)$, pyrite $\left(\mathrm{FeS}_{2}\right)$ and sphalerite $(\mathrm{ZnS})$.

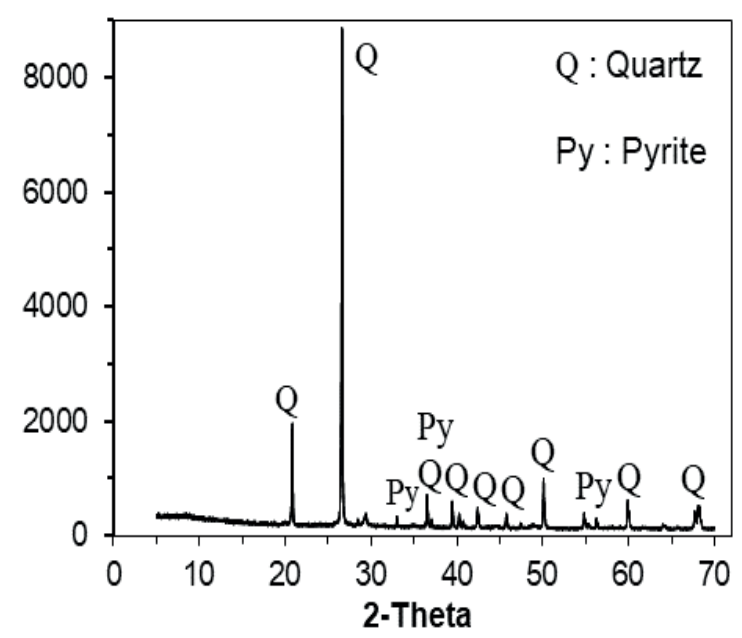

Figure 1. XRD profile of the ore sample
Table 3. Chemical composition of the ore sample

\begin{tabular}{cccc}
\hline $\begin{array}{c}\text { Element/ } \\
\text { Compound }\end{array}$ & $\begin{array}{c}\text { Content } \\
(\%)\end{array}$ & Element & $\begin{array}{c}\text { Content } \\
(\mathrm{g} / \mathrm{t})\end{array}$ \\
\hline $\mathrm{SiO}_{2}$ & 67.3 & $\mathrm{Au}$ & 107.7 \\
$\mathrm{Al}_{2} \mathrm{O}_{3}$ & 11.51 & $\mathrm{Cu}$ & 15960 \\
$\mathrm{Fe}_{2} \mathrm{O}_{3}$ & 6.06 & $\mathrm{Al}$ & 3900 \\
$\mathrm{MgO}$ & 0.45 & $\mathrm{Ni}$ & 604.5 \\
$\mathrm{CaO}$ & 0.46 & $\mathrm{Zn}$ & 926.1 \\
$\mathrm{Na}_{2} \mathrm{O}$ & 0.06 & $\mathrm{~Pb}$ & 838.1 \\
$\mathrm{~K}_{2} \mathrm{O}$ & 2.58 & $\mathrm{As}$ & 225 \\
$\mathrm{TiO}_{2}$ & 0.02 & $\mathrm{Ba}$ & 1211 \\
$\mathrm{P}_{2} \mathrm{O}_{5}$ & 0.19 & $\mathrm{Ag}$ & 9.3 \\
$\mathrm{MnO}_{\mathrm{Cr}}$ & 0.18 & $\mathrm{Sb}$ & 93.21 \\
$\mathrm{Cr}_{2} \mathrm{O}_{3}$ & 0.015 & $\mathrm{Mo}$ & 24.64 \\
$\mathrm{Fe}$ & 4.02 & $\mathrm{Cd}$ & 10.7 \\
$\mathrm{~S}$ & 3.46 & $\mathrm{La}$ & 1.64 \\
$\mathrm{~K}$ & 0.21 & $\mathrm{Na}$ & 270 \\
$\mathrm{Ca}$ & 0.22 & $\mathrm{Mg}$ & 710 \\
$\mathrm{P}$ & $0.001>$ & $\mathrm{Ti}$ & 23 \\
$\mathrm{LOI}$ & 6.03 & $\mathrm{Ga}$ & $5>$ \\
$\mathrm{Total} \mathrm{C}_{\mathrm{Total} \mathrm{S}}$ & 0.15 & $\mathrm{Bi}$ & $5>$ \\
$\mathrm{Sum}$ & 9.56 & $\mathrm{Hg}$ & $5>$ \\
\hline & 95.31 & $\mathrm{Be}$ & $1>$ \\
\hline
\end{tabular}

\subsection{Cyanide Leaching Tests with/without Acid Pretreatment}

Cyanide leaching tests were conducted in 1000$\mathrm{mL}$ Pyrex beakers for $24 \mathrm{~h}$ at room temperature. Mechanical stirrers equipped with PTFE coated four-blade $45^{\circ}$-pitched blade stainless steel impellers were used to agitate ore slurry. The diameter of these blade impellers was $6.4 \mathrm{~cm}$. Figure 2 shows the experimental set-up used in cyanide leaching.

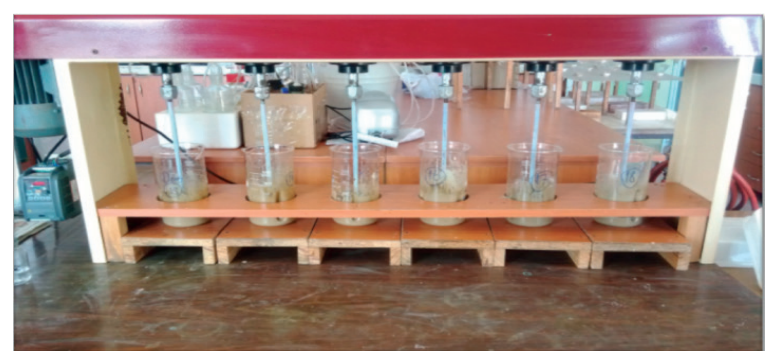

Figure 2. Multi mechanical stirrer set-up used in leaching tests 
$\mathrm{NaCN}(\geq 95 \%$, Merck) was used to prepare leach solutions at required concentrations. Stirring speed employed in reactors was $650 \mathrm{rpm}$. A solids ratio of $25 \% \mathrm{w} / \mathrm{w}$ (120 g ore $+360 \mathrm{~mL}$ solution) was maintained in the tests. Air was delivered by an air pump, into the leaching medium at a flow rate of $1.5 \mathrm{~L} / \mathrm{min}$. $\mathrm{pH}$ was adjusted to $10.5-11$ at which it was controlled over the leaching period by the use of lime. Samples $(6 \mathrm{~mL})$ were taken at certain intervals $(30 \mathrm{~min} .1 \mathrm{~h}, 2 \mathrm{~h}, 4 \mathrm{~h}, 8 \mathrm{~h}$ and $24 \mathrm{~h}$ ) and passed to a centrifuge to get clear solutions for the analysis of copper, gold, and silver by AAS. The titratable cyanide (essentially free cyanide as well as cyanide dissociated from metal (e.g. $\mathrm{Zn}$ and $\mathrm{Cu}$ ) cyanides) concentration was analysed by silver nitrate $\left(0.02 \mathrm{M} \mathrm{AgNO}_{3}\right)$ titration using $p$-dimethyl amino-benzyl-rhodanine as the indicator to determine cyanide consumption as well as to maintain the $\mathrm{NaCN}$ concentration at the initial level. A NaCN stock solution $(50 \mathrm{~g} / \mathrm{L})$ was used to keep the concentration of cyanide at the initial level over the leaching period. Following a leaching period of $24 \mathrm{~h}$, filtration was done for separation of leach residues. After drying in an oven at $105^{\circ} \mathrm{C}$ leaching residues were digested in a hot aqua regia for the analysis of metals. The extraction of metals was calculated based on the residual metal content. The relative standard deviation (RSD) of the metal recovery data was calculated based on replicate tests. The RSD for tests was found to be in the range of $\pm 0.6-1 \%$.

Acid pretreatment prior to cyanide leaching was also carried out to remove soluble copper using the same experimental set-up (Figure 2). Acid pretreatment was performed for $2 \mathrm{~h}$ in 1 $\mathrm{M} \mathrm{H}_{2} \mathrm{SO}_{4}$ solution prepared using concentrated acid $\left(\% 96 \mathrm{H}_{2} \mathrm{SO}_{4}\right)$ at room temperature. In these tests, $\mathrm{pH}$ was controlled at $<2$. The solids ratio and stirring speed were fixed at $25 \mathrm{w} / \mathrm{w}$ and $650 \mathrm{rpm}$, respectively. On the termination of the acid leaching test, the residue was thoroughly washed and separated by filtration, dried and then subjected to cyanide leaching under the conditions explained above.

\subsection{Ultra-fine Grinding (UFG) Pretreatment Prior to Cyanidation}

A laboratory-scale pin-type vertical stirred media mill was used to produce ultra-finely ground samples (Figure 3). UFG of the ore sample was done using $2 \mathrm{~mm}$ ceramic balls (alumina-based zirconia toughened, DMM AZ $2000^{\circledR}$ ) at $29 \% \mathrm{w} / \mathrm{v}$ $(\mathrm{S} / \mathrm{L})$ ratio and $650 \mathrm{rpm}$ stirring rate. The beads had $\mathrm{Al}_{2} \mathrm{O}_{3}$ content of $80 \%$, specific gravity (SG) of 3.75-3.80 and Vickers hardness (HV) of 1314 $\mathrm{N} / \mathrm{mm}^{2}$. The grinding time was 15,30 and 45 minutes which correspond to particle sizes $\left(\mathrm{d}_{80}\right)$ of $23 \mu \mathrm{m}, 15 \mu \mathrm{m}$ and $8 \mu \mathrm{m}$, respectively. Cyanide leaching tests were then carried out for the asreceived ore and the ground samples for a period of $24 \mathrm{~h}$.

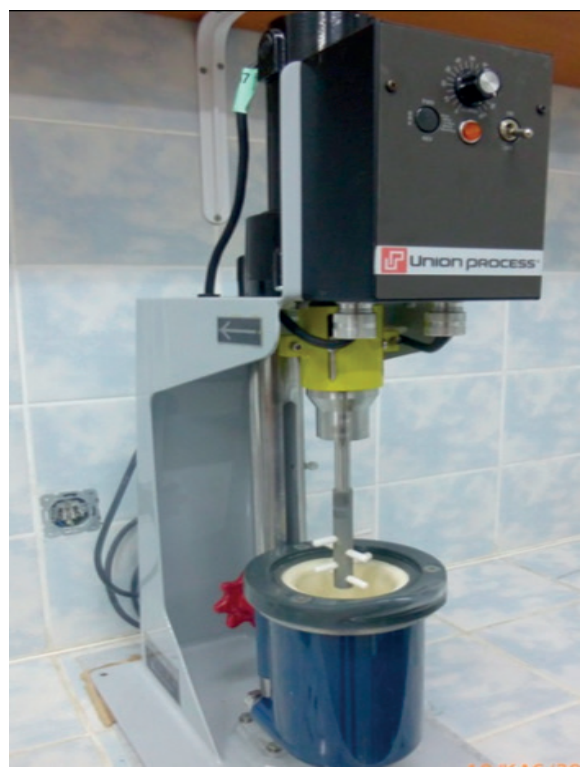

Figure 3. The stirred mill used in the ultra-fine grinding (UFG)

\section{RESULTS AND DISCUSSION}

\subsection{Cyanide Leaching with/without Acid Pretreatment}

Cyanide leaching of the ore with/without acid pretreatment was performed (Figure 4). Direct cyanide leaching of the ore at $1.5 \mathrm{~g} / \mathrm{L} \mathrm{NaCN}$ without any pretreatment resulted in very limited gold extraction of $18.4 \%$ at $24 \mathrm{~h}$ (Figure $4 \mathrm{a}$ ). This confirms that the ore is highly refractory. The total cyanide consumed in the leaching test was around $6.75 \mathrm{~kg} / \mathrm{t}$. This relatively high cyanide consumption suggested that copper and other cyanide consuming elements often exert a deleterious effect on the extraction of gold and reagent consumption. Previous studies have also reported low gold extractions in direct cyanide leaching of copper-gold ores. Bas et al. (2012) 
reported that the direct cyanidation of a copperrich gold ore $(56 \mathrm{~g} / \mathrm{t} \mathrm{Au}, 1.1 \% \mathrm{Cu})$ which has the same origin yielded poor recoveries $(<12 \%)$ of gold under the same cyanide leaching conditions. It was pointed out (Aylmore and Muir, 2001; Bas et al., 2012; Celep et al., 2018) that dissolution of copper minerals may adversely affect cyanidation leading to considerably high consumption of cyanide and markedly low recovery of gold.

Acid pretreatment $\left(1 \mathrm{M} \mathrm{H}_{2} \mathrm{SO}_{4}, 2 \mathrm{~h}\right.$ ) prior to cyanide leaching was also tested to eliminate copper interference through the dissolution of acidsoluble copper minerals in order to improve gold extraction in the subsequent cyanidation (Figure 4). It was found that in the acid pretreatment stage, $17.8 \%$ of copper was removed as well as $0.8 \% \mathrm{Ag}, 4.0 \% \mathrm{Fe}$ and $10.4 \% \mathrm{Zn}$ was dissolved over $2 \mathrm{~h}$. Compared with direct cyanide leaching this acid pretreatment appeared to lead to a $6.8 \%$ improvement in Au recovery in the subsequent cyanide leaching (Figure 4a). Silver extraction in the cyanide leaching was also observed to increase by 2.2-fold after acid pretreatment (Figure 4b). This could be also attributed to the effect of acid pretreatment allowing the exposure of silver minerals/phases associated with acidsoluble phases. Acid pretreatment remarkably reduced the cyanide consumption by $70.4 \%$ (i.e., from $6.75 \mathrm{~kg} / \mathrm{t}$ to $2.0 \mathrm{~kg} / \mathrm{t}$ ) in cyanide leaching. These findings (Figure 4a) also showed that acid pretreatment failed to improve the gold extraction to the desired extent i.e., gold recovery in cyanide leaching was limited to $25.2 \%$ after acid pretreatment. Yazici et al. (2015) investigated the effect of acid pretreatment $\left(\mathrm{H}_{2} \mathrm{SO}_{4}\right.$ with/ without $\mathrm{H}_{2} \mathrm{O}_{2}$ ) on the extraction of gold in cyanide leaching of a copper-rich gold ore (56 g/t Au, $1.1 \% \mathrm{Cu}$ ). Direct cyanide leaching was reported to extract only $6.7 \% \mathrm{Au}$ under typical cyanide leaching conditions (1.5 g/L NaCN, $24 \mathrm{~h}$ ). These researchers found that in the sulphuric acid pretreatment $\left(1 \mathrm{M} \mathrm{H}_{2} \mathrm{SO}_{4}, 25 \mathrm{w} / \mathrm{w}\right.$ solids ratio) the copper dissolution was $37-42 \%$ during the period of 0.5-6 $\mathrm{h}$. The gold extraction by cyanide leaching from the pretreated sample was reported to substantially increase to $99 \%$ over the short period of only $2 \mathrm{~h}$. Within this regard, the current findings (Figure 4) implies that the high copper content $(1.6 \%)$ of the ore used in the current study may not be apparently responsible for the low gold extractions in cyanide leaching.
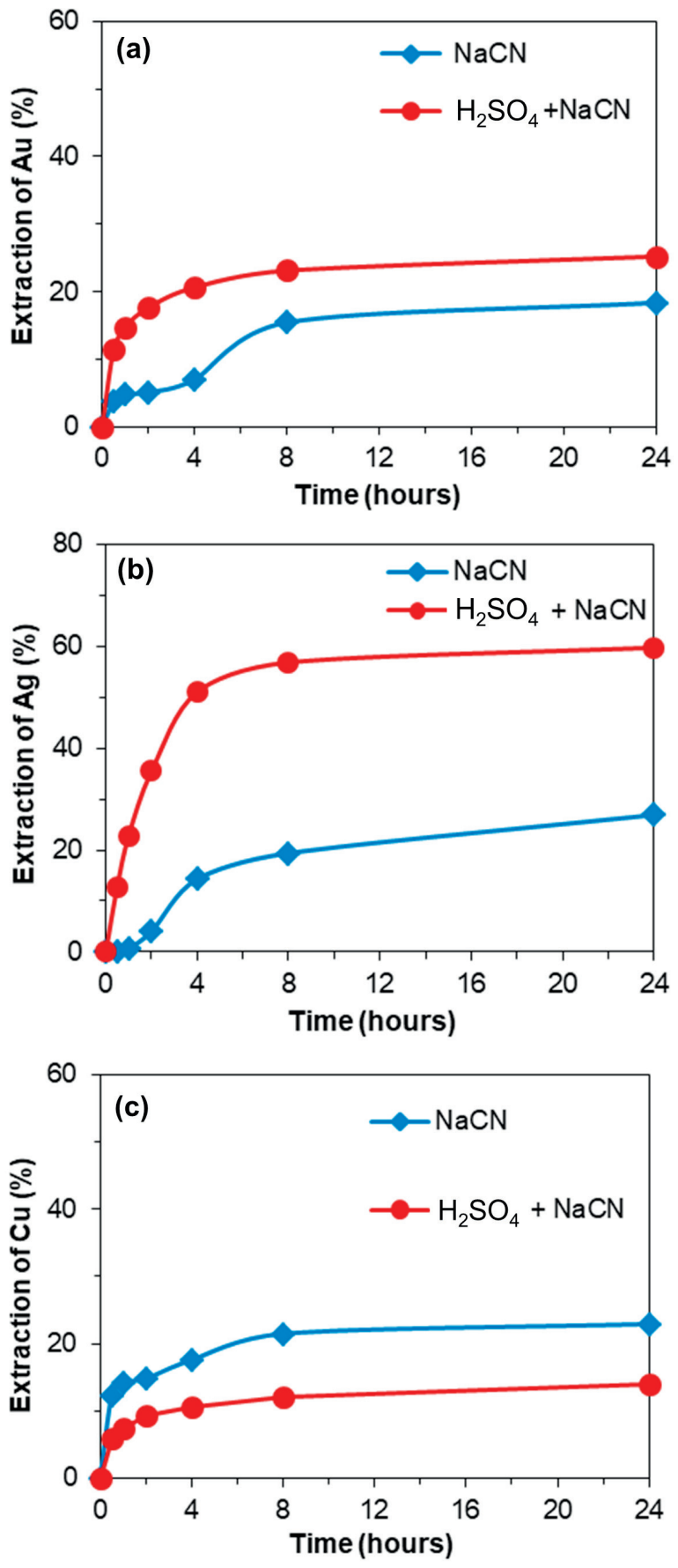

Figure 4. Extraction of gold (a), silver (b) and copper (c) in cyanide leaching ( $1.5 \mathrm{~g} / \mathrm{L} \mathrm{NaCN}, 25 \% \mathrm{w} / \mathrm{w}$ solids, Air flow rate: $1.5 \mathrm{~L} / \mathrm{min}, \mathrm{pH}$ 10.5-11) with/without $1 \mathrm{M}$ $\mathrm{H}_{2} \mathrm{SO}_{4}$ pretreatment $(2 \mathrm{~h})$

A series of leaching tests were also carried out at high cyanide concentrations (up to $8 \mathrm{~g} / \mathrm{L}$ $\mathrm{NaCN}$ ) in an attempt to increase gold recoveries by maintaining sufficiently high levels of cyanide (Figure 5). 

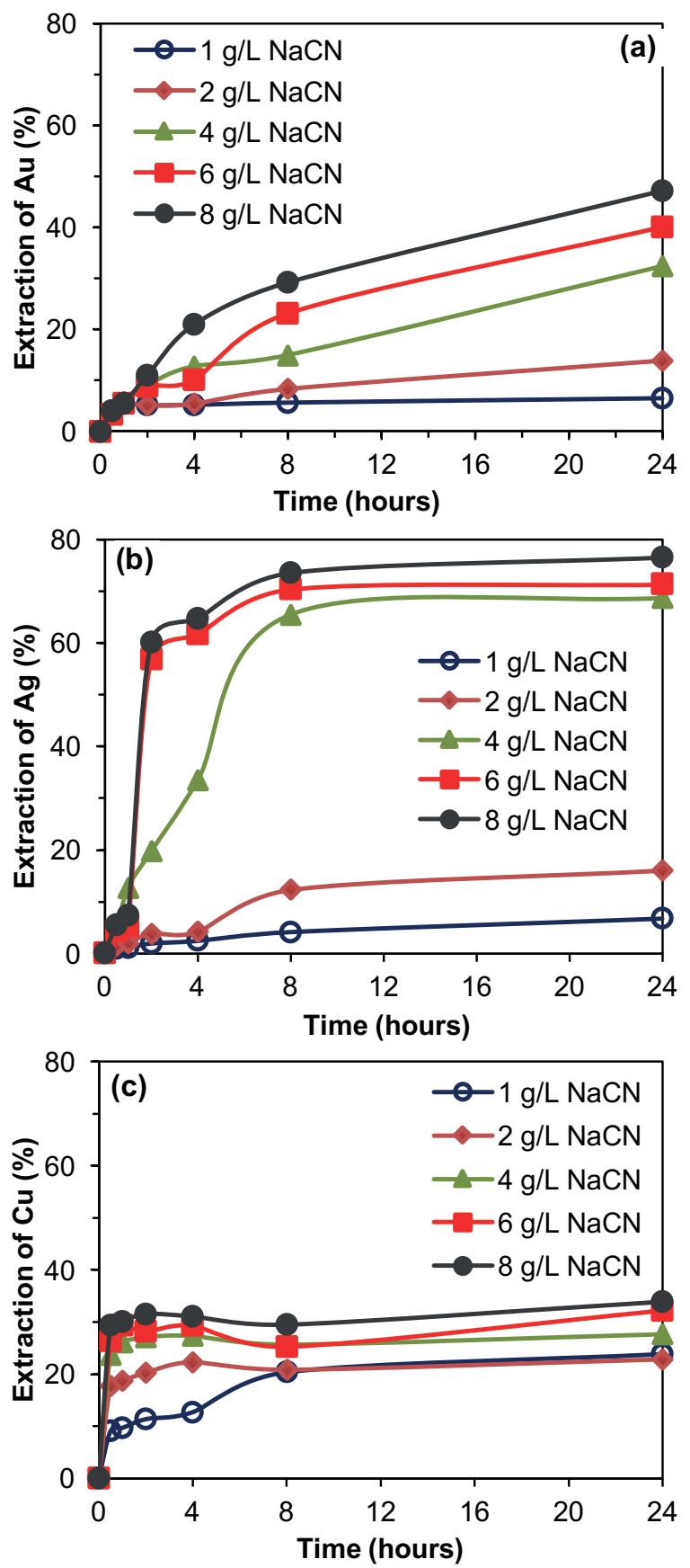

Figure 5. Effect of cyanide concentration on the extraction of gold (a), silver (b) and copper (c) (Leaching time: 24 h., Air flow rate: $1.5 \mathrm{~L} / \mathrm{min}, 25 \% \mathrm{w} / \mathrm{w}$ solids ratio, $\mathrm{pH} 10.5-11$ )

Increasing the cyanide concentration did not produce the desired effect. Only $47.2 \%$ of gold was extracted at the highest $\mathrm{NaCN}$ level of $8 \mathrm{~g} / \mathrm{L}$ (Figure $5 a$ ). Silver extraction was improved from $6.7 \%$ ( $1 \mathrm{~g} / \mathrm{L} \mathrm{NaCN})$ to $76.4 \%$ (8 g/L NaCN) (Figure $5 b)$. This gave a clear picture of how reagent could be wasted in treating such kind of ores, yet the gold extractions still remain unacceptably poor. A slight change of about $10 \%$ for copper extraction was observed i.e. from $23.86 \%(1 \mathrm{~g} / \mathrm{L}$ $\mathrm{NaCN}$ ) to $33.9 \%$ (8 $\mathrm{g} / \mathrm{L} \mathrm{NaCN})$. On the contrary to the current findings (Figure 5a), Bas et al. (2015) found that high gold extractions ( $>97 \%$ ) could be achieved by cyanide leaching of a copper-rich gold ore $(56 \mathrm{~g} / \mathrm{t} \mathrm{Au}, 1.1 \% \mathrm{Cu})$ at $>5 \mathrm{~g} / \mathrm{L} \mathrm{NaCN}$.

Increasing the cyanide concentration (Figure 6) was also noted to further aggravate the cyanide consumption. A 5.54-fold increase (i.e., from 3.1 $\mathrm{kg} / \mathrm{t}$ to $17.2 \mathrm{~kg} / \mathrm{t}$ ) in the reagent consumption was recorded by increasing the initial cyanide level from $1 \mathrm{~g} / \mathrm{L}$ to $8 \mathrm{~g} / \mathrm{LNaCN}$. Copper minerals are particularly responsible for high reagent consumption given their comparatively high solubility $(17.8 \%$ acidsoluble copper present in the ore, Figure 4) in cyanide solutions (Equations 1-5).

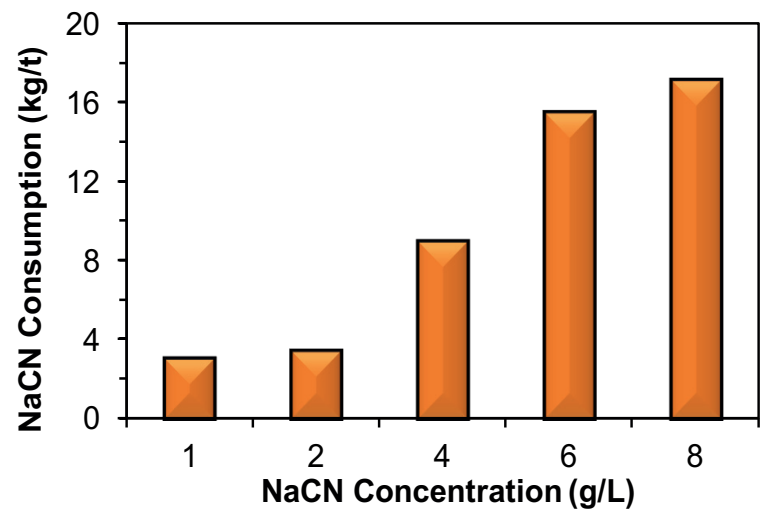

Figure 6. Total cyanide consumptions (kg $\mathrm{NaCN}$ per tonne ore) at different cyanide concentrations (Leaching time: 24 h., Air flow rate: $1.5 \mathrm{~L} / \mathrm{min}, 25 \% \mathrm{w} / \mathrm{w}$ solids ratio, $\mathrm{pH} 10.5-11$ )

Figure 7 shows the speciation of copper(I)-cyanide complexes as a function of the concentration of cyanide. Other side reactions may also contribute further to cyanide consumption such as the formation of thiocyanate through reactions with sulphide minerals (Equations 3,5), reaction of other metals with cyanide, reduction of copper(II) released from $\mathrm{Cu}(\mathrm{II})$-sulphides, $\mathrm{Cu}(\mathrm{II})$ catalysed oxidation of cyanide in the presence of air, increased the consumption of cyanide and partial volatilisation of cyanide as HCN (Adams, 2016; Hayes and Corrans, 1992; Yazici et al., 2009). 


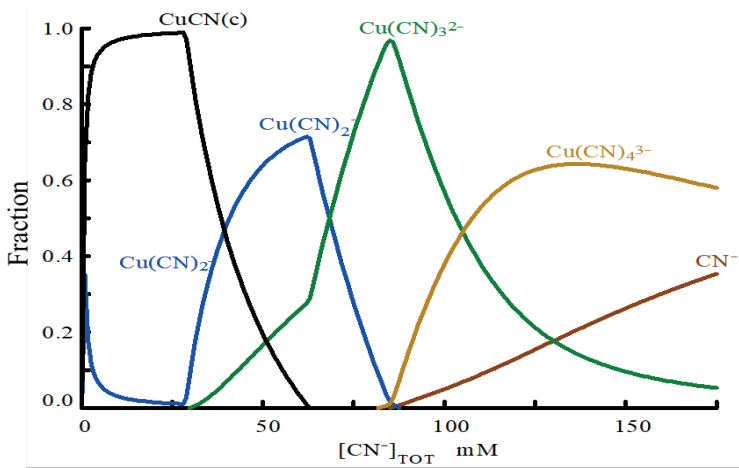

Figure 7. Speciation of copper(I)-cyanides depending on the concentration of cyanide $(\mathrm{Cu}(\mathrm{l}): 29 \mathrm{mM}, \mathrm{pH}$ 10.5, $25^{\circ} \mathrm{C}$ ) (Medusa, 2009).

It can be inferred from these findings (Figures 4-6) that the low gold extraction is not only linked with the presence of copper in the ore. Intensive cyanide leaching and acid pretreatment for leaching/ removing copper prior to cyanide leaching exerted a limited enhancing effect on gold extraction. This suggests that the remained refractory gold may be present as locked-up in pyrite and/or nonsulphide gangue minerals. Therefore, ultra-fine grinding ahead of intensive cyanide leaching at $8 \mathrm{~g} / \mathrm{L} \mathrm{NaCN}$ was also investigated to reveal the possible physical refractoriness of the ore.

\subsection{Effect of Ultra-fine Grinding (UFG)}

This approach was employed as a physical pretreatment to enhance the extraction of gold. This technique is applied to set free the grains of gold finely distributed in gangue minerals. The ore samples $\left(d_{80}=73 \mu \mathrm{m}\right)$ ground for 15 , 30 and 45 minutes resulted in the production of materials with a fineness $\left(d_{80}\right)$ of $23 \mu \mathrm{m}, 15 \mu \mathrm{m}$, $8 \mu \mathrm{m}$, respectively. Figure 8 illustrates the results of cyanide leaching of the ground samples for 24 hours. There was no remarkable effect of the ultra-fine grinding on the extraction of gold, even though the sodium cyanide concentration used in this experiment was kept high at $8 \mathrm{~g} / \mathrm{L}$ (Figure 8a). Reducing the size of the ore from $73 \mu \mathrm{m}$ to $15 \mu \mathrm{m}$ produced only a limited improvement by $6.9 \%$ in gold extraction i.e., from $47.2 \%$ to $54.1 \%$. Further reduction in the ore size from $15 \mu \mathrm{m}$ to $8 \mu \mathrm{m}$ appeared to adversely affect the gold extraction with a $7.74 \%$ reduction (Figure $8 a$ ). This could be linked with the increased reagent consumption due to the formation of more active/fresh surfaces and/or, coating/passivation of gold and goldcarrying minerals by fine particles (slime). UFG also did not enhance the extraction of silver (not shown). Copper dissolution appeared to be increased by $24 \%$ with grinding the ore from 73 $\mu \mathrm{m}$ to $8 \mu \mathrm{m}$ (Figure $8 \mathrm{~b}$ ). The limited improvement of gold/silver extraction by UFG can be attributed to the liberation/exposure of the physically encapsulated gold/silver grains at these sizes, allowing their contact with cyanide.

On the contrary to the current findings (Figure 8), some researchers reported the beneficial effect of UFG on the extraction of gold by cyanide leaching. Celep et al. (2016) noted a significant improvement (from $45 \%$ to $85 \%$ ) in the gold extraction from a pyritic concentrate after ultrafine grinding as a pretreatment method before the cyanidation. They reported that fine grinding of the concentrate, as well as high cyanide concentrations ( $>5 \mathrm{~g} / \mathrm{L}$ ), are required to achieve acceptably high gold extractions. Ellis and Gao (2002) also observed a $19.7 \%$ enhancement in the extraction of gold (from $74.3 \%$ to $93.9 \%$ ) at Kalgoorlie Consolidated Gold Mines (KCGM) after UFG of the ore from $130 \mu \mathrm{m}$ to $5 \mu \mathrm{m}$.
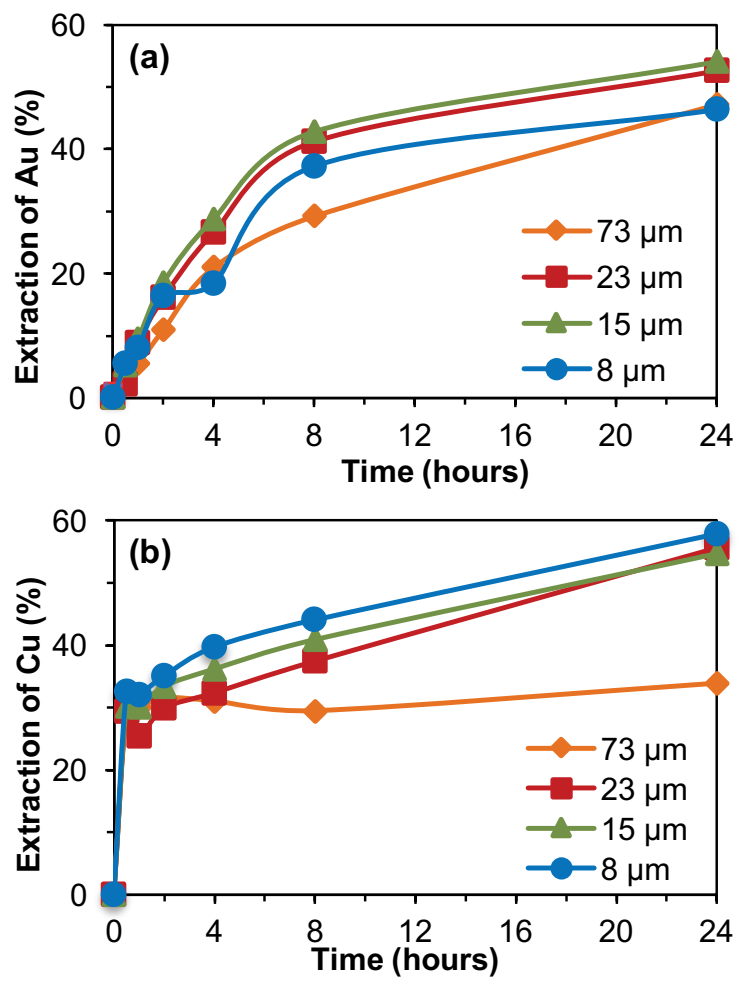

Figure 8. Effect of ultra-fine grinding on the extraction of gold (a) and copper (b) (8 g/L NaCN, 25\% w/w solids ratio, Air flow rate: $1.5 \mathrm{~L} / \mathrm{min}, \mathrm{pH} 10.5-11$ ) 
Figure 9 depicts the effect of decreasing particle size on the amount of total cyanide consumed over the leaching period of 24 hours. The cyanide consumption increased (by 1.77-fold) from 17.2 $\mathrm{kg} / \mathrm{t}$ to $30.4 \mathrm{~kg} / \mathrm{t}$ with UFG of the ore from $73 \mu \mathrm{m}$ to $8 \mu \mathrm{m}$. This is apparently concomitant with the increased dissolution of copper (Figure 8b) and probably other cyanide-consuming constituents due to the expected increase in surface area or activation of minerals. Ellis and Gao (2002) also observed a beneficial effect of UFG from $130 \mu \mathrm{m}$ to $5 \mu \mathrm{m}$ on gold extraction at the expense of 7.1fold higher cyanide consumption.

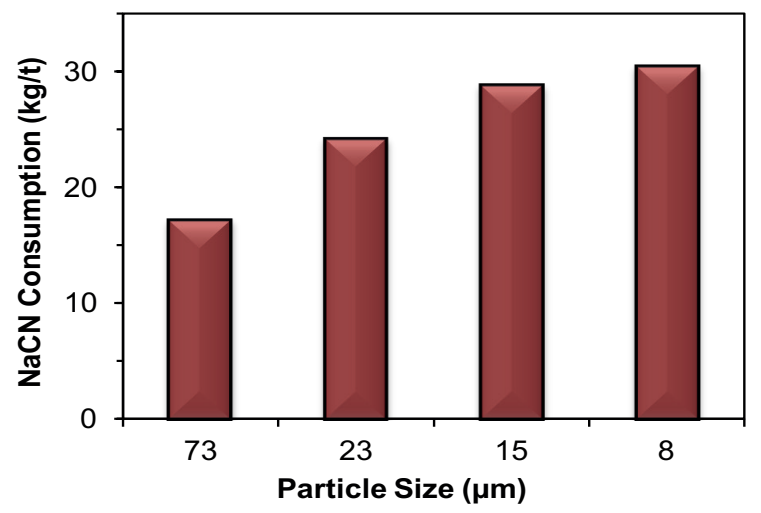

Figure 9. Total cyanide consumptions (kg NaCN per tonne ore) at different particle sizes (Leaching time: $24 \mathrm{~h}$., Air flow rate: $1.5 \mathrm{~L} / \mathrm{min}, 25 \% \mathrm{w} / \mathrm{w}$ solids ratio, $\mathrm{pH} 10.5-11$ )

These findings (Figures 4-9) revealed that gold recoveries were still low $(<54.1 \%)$ even when the ultra-finely ground ore (down to $8 \mu \mathrm{m}$ ) was subsequently leached at high levels of cyanide (i.e., $8 \mathrm{~g} / \mathrm{L} \mathrm{NaCN}$ ). This suggests that the ore can be classified as a double-refractory gold ore due to its high copper content and the presence of gold apparently recalcitrant to cyanidation. Chemical pretreatment methods such as roasting/biooxidation/pressure oxidation, which are capable of improving gold extraction from sulphide ores, should be therefore tested for eliminating the refractoriness of the ore before cyanide leaching.

\section{CONCLUSION}

The recovery of gold from a copper-rich gold ore (108 g/t Au, $1.60 \% \mathrm{Cu}$ ) by cyanide leaching was investigated. Low gold recoveries (18.4\% over 24 h.) obtained by direct cyanide leaching (1.5 g/L $\mathrm{NaCN}$ ) indicated highly refractory nature of the ore. Acid pretreatment $\left(1 \mathrm{M} \mathrm{H}_{2} \mathrm{SO}_{4}\right)$ tested for the removal of acid-soluble copper was found to improve cyanide leaching of gold only to a limited extent. The ore was also leached at high cyanide concentrations i.e., up to $8 \mathrm{~g} / \mathrm{L} \mathrm{NaCN}$, to overcome soluble copper interference with gold extraction. However, it was limited to $47.2 \% \mathrm{Au}$ even at the highest level of $\mathrm{NaCN}$ concentration $(8 \mathrm{~g} / \mathrm{L})$ tested. To eliminate the physical refractoriness of the ore, ultra-fine grinding (UFG) $\left(\mathrm{d}_{80}\right.$ : from $73 \mu \mathrm{m}$ to $8 \mu \mathrm{m}$ ) prior to cyanide leaching was also carried out at $8 \mathrm{~g} / \mathrm{L} \mathrm{NaCN}$. UFG did not enhance the extractions of gold, to the desired extent, which was limited to $\leq 54.1 \% \mathrm{Au}$. Low gold extractions obtained using these pretreatments and intensive cyanide leaching indicate the refractory nature of the ore, apparently linked with the encapsulation of very fine gold in sulphides e.g., pyrite as well as chemical interference of reactive minerals with cyanide leaching. It can be inferred that chemical pretreatment options such as roasting, biooxidation and pressure oxidation should be examined to increase the exposure of gold grains locked-up within sulphides.

\section{ACKNOWLEDGEMENTS}

The authors would like to thank Mastra Gold Mine (Koza Gold Operations) for providing the ore sample and Dakot Milling Media (Pty) Ltd (South Africa) for kindly providing the ceramic microgrinding beads (DMM AZ 2000 ${ }^{\circledR}$ ). The financial support by the Office of Scientific Research Projects of Karadeniz Technical University (Project no's: FBA-2018-7399) is gratefully acknowledged.

\section{REFERENCES}

Adams, M. D., 2016. Gold Ore Processing: Project Development and Operations. Second Ed, ISBN 9780-444-63658-4, Vol 15, Elsevier.

Ahlatcı, F., Koç, E., Kuzu, M., Yazıcı, E., Celep, O., Deveci, H., 2016. Sulphide Precipitation of Gold and Silver from Thiosulphate Leach Solutions. XV. International Mineral Processing Symposium, Istanbul, Turkey, 750-760

Ahlatcı, F., Yazıcı. E.Y., Celep, O., Deveci, H., 2018. Thiosulphate Leaching of Gold/Silver from a CopperBearing Pyritic Gold Concentrate. XXIX. International Mineral Processing Congress (IMPC), Paper no: 185, 17-21. 
Akçay, M., Gündüz, Ö., 2004. Porphyry Cu-Au Mineralisation Associated with a Multi-Phase Intrusion and Related Replacement Fronts in Limestones in an Island Arc Setting Near the Gümüşhane Village (Artvin) In The Eastern Black Sea Province (Turkey). Chemie Der Erde - Geochemistry, 64, 359-383.

Aylmore, M.G., Muir, D.M., 2001. Thiosulphate Leaching of Gold- A Review. Minerals Engineering, 14, 135-174.

Bas, A. D., Koç, E., Yazici, E. Y., Deveci, H., 2015. Treatment of Copper-Rich Gold Ore by Cyanide Leaching. Leaching. Trans Nonferrous Met. Soc. China, 25 (2), 597-607.

Bas, A. D., Yazici, E. Y., Deveci, H., 2012. Treatment of Copper Rich Gold Ores by Ammonia Assisted Cyanide Leaching. Proceedings of the XXVI International Mineral Processing Congress (IMPC), New Delhi, India, 356-365.

Bascombe, L., Mach, L., Altman, K.A., 2013. Technical Report on the Çöpler Mineral Resource Update Erzincan Province. Turkey, No. Canadian National Instrument, 43-101, Alacer Gold.

Celep, O., 2011. Application of Alkaline Pretreatments for Gold and Silver Recovery from Refractory Ores. PhD Thesis, Karadeniz Technical University. The Graduate School of Natural and Applied Sciences, Department of Mining Engineering, Trabzon, May, 157 pp.

Celep, O., 2015. Processing of Gold Ores. Türkiye Alim Kitapları, 220 pp (in Turkish).

Celep, O., Altınkaya, P., Yazıcı, E.Y., Deveci, H., 2016. Effect of Ultra-fine Grinding on Cyanide Leaching of Copper Bearing Pyritic Gold Concentrate. Proceedings of XV. International Mineral Processing Symposium and Exhibition (IMPS), Istanbul-Turkey, 1255-1269.

Celep, O., Altinkaya, P., Yazıcı, E.Y., Deveci, H., 2018. Nitric Acid Leaching for Pre-Treatment of a Copper Bearing Auroferrous Pyritic Concentrate. XXIX. International Mineral Processing Congress (IMPC), Paper no: 184, 17-21.

Chryssoulis, S.L., Mcmullen, J., 2016. Mineralogical Investigation of Gold Ores. Gold Ore ProcessingProject Development and Operations. Editor Mike Adams, Elsevier, 57-93.

Deveci, H., Yazici, E.Y., Celep, O., 2018. An Overview of Pre-treatment and Leaching Options for Gold Extraction from Refractory Copper-Gold Ores. 16th International Mineral Processing Symposium and Exhibition (IMPS), Antalya, 439-451.

Ellis, S., Gao, M., 2002. The Development of Ultra-fine Grinding at KCGM. SME Annual Conference, Preprint 02-072.

Fleming, C.A., Mezei, A., Bourricaudy, E., Canizares, M., Ashbury, M., 2011. Factors Influencing the Rate of Gold Cyanide Leaching and Adsorption on Activated Carbon, and their Impact on the Design of CIL and CIP Circuits. Minerals Engineering, 24, 6, 484-494.

Fleming, C.A., 2011. Dealing with Cyanide-Soluble Copper in the Gold Mining Industry. Fray International
Symposium on Metals and Materials Processing in a Clean Environment. Mexico, 173-190.

Habashi, F., 1999. A Textbook of Hydrometallurgy. Metallurgie Extractive Quebec Publications, Canada, 220-223.

Hayes, G. A., Corrans, I. J., 1992. Leaching of GoldCopper Ores Using Ammoniacal Cyanide. Proceedings of International Conference on Extractive Metallurgy of Gold and Base Metals, Melbourne, Australasian Inst Min Metall, 349-353.

Hedley, N., Tabachnick, H., 1958. Chemistry of Cyanidation. Mineral Dressing Notes No. 23, American Cyanamid Company, New Jersey.

Kesler, S.E., Chryssoulis, S.L., Simon, G., 2002. Gold in Porphyry Copper Deposits: Its Abundance and Fate. Ore Geology Review, 21 (1-2), 103-124.

Marsden, J., House, I., 2006. The Chemistry of Gold Extraction. $2^{\text {nd }}$ Edition, The Society for Mining Metallurgy and Exploration Inc., USA, 318-392.

Medusa, 2009. Software for Chemical Equilibrium Diagrams. 32 bit version, Royal Institute of Technology, Sweden.

Muir, D.M., 2011. A Review of the Selective Leaching of Gold from Oxidized Copper-Gold Ores with AmmoniaCyanide and New Insights for Plant Control and Operation. Minerals Engineering, 24, 576-582.

Sceresini, B., Breuer, P., 2016. Gold-copper Ores. Gold Ore Processing, $2^{\text {nd }}$ Edition, Chapter 43, Editor: Adams, M. D., Elsevier.

Sinclair, W.D., 2007. Porphyry Deposits. Geological Association of Canada, Mineral Deposits Division, Special Publication, Canada, 223-243.

URL-1,http://kozaaltin.com.tr/operasyonlar-ve-projeler/ kaymaz-altin-madeni, 02 August 2013.

URL-2, https://www.alacergold.com/operations/ resources-and-reserves, 29 July 2020.

URL-3, http://marianaresources.com/projects/hotmaden/ 24 March 2016.

Yazici, E. Y., Deveci, H., Alp, I., 2009. Treatment of Cyanide Effluents by Oxidation and Adsorption in Batch and Column Studies. Journal of Hazardous Materials, 166 (2-3), 1362-1366.

Yazici, E.Y., Ahlatci, F., Koc, E., Celep, O., Deveci, H., 2015. Pre-treatment of a Copper-rich Gold Ore for Elimination of Copper Interference. $8^{\text {th }}$ European Metallurgical Conference (EMC), Dusseldorf, Vol. 2, 601-613.

Yılmaz, E., Yazıcı, E.Y., Celep, O., Deveci, H., 2019. Recovery of Cyanide from Effluents: SART Process. Gumushane University Journal of Science and Technology Institute, 9 (3), 600-615 (in Turkish).

Yigit, O., 2006. Gold in Turkey- A Missing Link in Tethyan Metallogeny. Ore Geology Reviews, 28, 147179. 